\title{
SEXING THE SUBJECT OF TRANSITIONAL JUSTICE
}

\begin{abstract}
Susan Harris Rimmer*
Our argument is...that international law does not provide even momentary distance from subjectivity. It is intertwined with a sexed and gendered subjectivity, and reinforces a system of male power. Until international law focuses on all people and peoples, not just a powerful few, it will always be subject to geopolitical agendas inimical to genuine security... ${ }^{1}$
\end{abstract}

\subsection{INTRODUCTION}

This article describes the theoretical approaches of the international legal and realist schools to transitional justice, and analyses the feminist challenges to these approaches. Martin Luther King Junior in his celebrated letter from Birmingham Jail on 16 April 1963 differentiated between those who prefer 'a negative peace which is the absence of tension' to 'a positive peace which is the presence of justice'. ${ }^{2}$ Transitional justice processes in a post-conflict state often claim as an ultimate objective not just the alleviation of tension but the positive 'presence' of justice. ${ }^{3}$ Yet when this broader theme is considered, this objective of transitional justice and the audience who will one day feel this presence of justice are often presumed to be gender-neutral.

My argument is that feminist scholarship in the transitional justice field has managed to both inform and transform the stalled 'realist' and 'legalist' debates about the obligation to punish in post-conflict states. Section 2.0 of the article defines and summarises these debates. Under the 'legalist' approach, international law is central to the project of transitional justice because it imposes an obligation on states to punish individuals guilty of the most serious violations of international law, and this determines that trials must be among the mechanisms chosen. The counter-point to this position, posed by the 'realist' school of international relations, is that these

* Dr Susan Harris Rimmer is an ARC-funded researcher with the Centre for International Governance and Justice at the Regulatory Institutions Network, Research School of Pacific and Asian Studies, the Australian National University, Canberra ACT 0200. susan.harris-rimmer@anu.edu.au. Many thanks to Hilary Charlesworth and Penelope Mathew, as well as the AFLJ reviewers for comments.

1 Chinkin Christine, Charlesworth Hilary and Wright Shelley 'Feminist approaches to international law: reflections from another century' in Buss Doris and Manji Ambreena (eds) International Law: Modern Feminist Approaches Hart Publishing Oxford and Portland Oregon 2005 p 44.

2 King Martin Luther Jr (ed) 'Letter from Birmingham Jail' in Wby We Can't Wait Harper and Row New York 1963 at $77-$ 100.

3 Mani Rama 'Editorial: Dilemmas of Expanding Transitional Justice, or Forging the Nexus between Transitional Justice and Development' (2009) 2 International Journal of Transitional Justice (Special issue on transitional justice and development) 253. 
choices should be left entirely to the post-conflict state concerned in the interests of democracy and stability. 'Strategic legalism' is a school of thought that argues that accountability mechanisms such as trials are not mandatory, and should have social objectives beyond the punishment of the individual, such as providing the setting for social deliberations about justice.

Feminist theorists have made many contributions to realist/legalist debates in their respective disciplines more generally. Influenced by these insights, feminists in the transitional justice field ask a different set of questions that strain the boundaries of the disciplines, as set out in Section 3.0. Feminist analysis can ask whether non-male elites in a particular society have in fact experienced a transition from conflict to peace at all, or whether violence and deprivation has continued unabated for certain segments of the population. I call this phenomenon 'changing the curtains'. A feminist legalist can interrogate the idea that if international law has the central role ascribed to it by legalists, we might expect its impact on women involved in the relevant transitional justice processes to be beneficial for women in an immediate post-conflict setting. As noted by Judith Gardam in this special issue, the project of most feminist international lawyers has been to extend the obligation to punish to the category of crimes committed against women in armed conflict so that the rule of law will be equally applied to women and men. This has meant the adoption of a legalist position. ${ }^{4}$

If the realist position has more explanatory power, what would be its outcomes for women? The feminist realist position can explain why justice issues, just as gender considerations, can be marginalised in transitions and post-conflict situations. Trying to mainstream gender into legal frameworks that are at the margins of political processes has its own set of challenges. In most cases, even the most high profile transitional justice mechanisms such as justice components in peace deals, truth commissions and trials have come about after hard political negotiations and inevitable compromises. This may contribute to pushing gender considerations even further off the agenda.

The 'feminist strategic legalist' critique developed here posits that both traditional theoretical positions are based on the absence and silence of women. So-called 'realist' international relations theorists focus only on elite men as the subject of discourse and do not describe the reality of women's lives or the complexity of gender roles,${ }^{5}$ but for much the same reasons the gendered nature of international law means that it too will be resistant to the lived experience of women. ${ }^{6}$ A feminist strategic legalist is defined here to mean a feminist who stands against Realpolitik impunity but is also sceptical of the claims made about criminal trials in a postconflict setting in relation to gender concerns. Section 4.0 assesses three transitional issues using the idea of feminist strategic legalism: the representation of women in transitional justice processes, the categorisation of crimes, and prosecution strategies and problems.

4 See especially Millar Hayli ‘Facilitating Women's Voices in Truth Recovery: An assessment of women's participation and the integration of a gender perspective in truth commissions' in Durham Helen and Gurd Tracey (eds) Listening to the Silences: Women and War Martinus Nijhoff Boston Leiden 2005 p 171.

5 Pettman Jan Jindy Worlding Women: A Feminist International Politic Allen and Unwin St Leonards 1996 p 5.

6 See especially Engle Karen 'Feminism and Its (Dis)contents: Criminalizing Wartime Rape in Bosnia and Herzegovina' (2005) 99(4) American Journal of International Law 778. 
My analysis confirms Dianne Otto's claims that the international struggle for the full inclusion of women in the paradigm of universal human rights has reached a point where it needs reinvention'. ${ }^{7}$ In light of this, in this final section of this article, I consider ideas that could 'reinvent' approaches to transitional justice, ideas that may require an 'omnidisciplinary' approach. If transitional justice interventions cannot be inclusive of women's experiences of the conflict and post-conflict periods, then it may be a more strategic approach to pursue other non-legal strategies against impunity, or at least a re-gendered legalist model. Jacqui True's article in this issue reminds us of the importance of economic analyses of violence against women, and economic empowerment as a possible solution. One such is a reinvention (or subversion) of the concept of a war veteran, to give women and children the legal status and benefits of a veteran in the same manner as a combatant if their suffering has contributed to or been a consequence of the struggle for independence.

\subsection{THEORETICAL IDEAS ABOUT TRANSITIONAL JUSTICE: LEGALISM AND REALISM}

\subsection{Legalist Views}

Transitional justice studies focus on what it means for a nation to come to terms with a violent past and what to do with the perpetrators of the violence. This is usually done by analysing accountability mechanisms at a point of transition for those accused of having committed human rights violations during the prior regime. ${ }^{8}$ Transitional justice practice has evolved as part of international involvement in transitions or post-conflict situations since World War II. Transitional justice research has evolved at the crossroads between international law and political science. Analysis relating to transitional justice studies from the perspective of international law has mainly been limited to those conflicts where international criminal trials have been held. ${ }^{9}$ For example, the Nuremberg and Tokyo trials held after World War II, and the ad hoc tribunals set up by the UN Security Council to deal with international crimes committed in the Former Yugoslavia and Rwanda have been closely examined.

Legalist scholarship tends to deal with the conduct of the trials, the development of jurisprudence or the content of international criminal law, and the creation of the International

7 Otto Dianne 'Disconcerting "Masculinities": reinventing the gendered subject(s) of international human rights law' in Buss and Manji International Law: Modern Feminist Approaches above note 1 at 128.

8 See especially Hayner Priscilla B Unspeakable Truths: Confronting State Terror and Atrocity Routledge New York 2001; Minow Martha Between Vengeance and Forgiveness: Facing History After Genocide and Mass Violence Beacon Press Boston 1998; and Teitel Ruti G Transitional Justice Oxford University Press New York 2000.

9 See eg Best Geoffery Humanity in Warfare: The Modern History of the International Law of Armed Conflict Weidenfeld and Nicholson London 1980. The exception to this is the important collection Bassiouni M Cherif (ed) Post-Conflict Justice Transnational Publishers New York 2002. 
Criminal Court. ${ }^{10}$ In other words, legalist scholarship in the transitional justice field has been almost exclusively trials-focused. The overwhelming majority of international law academics advocate the holding of trials as the preferred accountability option for post-conflict settings. ${ }^{11}$ This is also the view of the UN secretariat. ${ }^{12}$ Where legalist scholarship is critical, it tends to focus on the question of whether amnesties given in relation to truth commissions comply with international law,,$^{13}$ or whether trials are better than truth commission processes or no process at all. ${ }^{14}$

Emerging scholarship addresses this question of the presence of justice for the ordinary population in a post-conflict setting. It is now said regularly in the literature that transitional justice trial mechanisms should support the rule of law in post-conflict states. This is because the task of transitional justice is in part forward-looking; to ensure that 'never again' will violations reoccur in the society. The reason for this support for the dual role of law in a post-conflict state is a belief in the transformative value of transitional justice processes. For example, the leading academic in transitional justice studies, Ruti Teitel, states that transitional criminal justice 'does not simply advance the conventional purposes of punishment in a rule-of-law state' but that the law in a transitional period holds an 'independent potential for effecting transformative politics' and 'liberalising' change. ${ }^{15}$ She suggests that there is no universal norm but rather that, transitional justice measures may be 'partial, contextual and multiple'. ${ }^{16}$ In other words, trials can and should assist the efforts to restore the justice sector in a society where the rule of law has broken down or been weakened as a result of conflict. ${ }^{17}$

The impact of international law that causes the most friction in transitional justice debates is the imposition on a state of the obligation to punish, because this necessarily limits the options a new state has at its disposal to deal with past violations, including the option of doing nothing. ${ }^{18}$ The legalist position is based on the characterisation of international crimes as jus cogens norms of international law; peremptory and non-derogable norms which are fundamental to the interests of

10 See further Roht-Arriaza Naomi and Mariezcurrena Javier (eds) Transitional Justice in the Twenty-First Century: Beyond Truth versus Justice Cambridge University Press Cambridge 2006.

11 Miriam Aukerman describes this as the 'prosecution preference'. See Aukerman Miriam 'Extraordinary Evil, Ordinary Crime: A Framework for Understanding Transitional Justice’ (2002) 15 Harvard Human Rights Journal 39 at 47.

12 Secretary General United Nations Report to the Security Council, on the Rule of Law and Transitional Justice in Conflict and PostConflict Societies United Nations Doc S/2004/616 23 August 2004.

13 See further O'Shea Andreas Amnesty for crime in international law and practice Kluwer Law International The Hague 2002.

14 Orentlicher Diane E 'Settling Accounts: The Duty to Prosecute Human Rights Violations of a Prior Regime' (1991) 100 Yale Law Journal 2537. See also Robertson Geoffrey Crimes Against Humanity: The Struggle for Global Justice New Press London and New York 2000 particularly his discussion of amnesties at p 263.

15 Teitel above note 8 at 6 .

16 As above. See also Leebaw Bronwyn 'Book Review: Transitional Justice by Ruti Teitel' (2001) 49 American Journal of Comparative Law 363 at 364.

17 See further the International Commission on Intervention and State Sovereignty, The Responsibility to Protect Report of the International Commission on Intervention and State Sovereignty (December 2001) p 42.

18 As an example, Mozambique has taken this course. Certain conflicts with very low political value to the international community can be left completely unaddressed, such as Ethiopia, despite over one million casualties under the Mengitsu regime. 
the international community. ${ }^{19}$ All states have a joint legal interest in the protection of jus cogens norms (i.e. they are applied erga omnes), because they are crimes that threaten the peace and security of humankind and shock the conscience of humanity. ${ }^{20}$ Protection under international humanitarian law (IHL), including the primary instruments of the 1949 Geneva Conventions, is firmly based on three rules that acknowledge this jus cogens basis: (a) IHL is not subject to reciprocity; (b) victims cannot give up or waive their rights to protection; and (c) IHL is consistent, and does not discriminate. ${ }^{21}$

M. Cherif Bassiouni argues that, despite the clear obligation to prosecute certain crimes under international law, the current paradigm is that of unfettered 'tradeability' around transitional justice decisions. Bassiouni and other legal experts such as Diane Orentlicher instead favour a legalist or 'minimum accountability' approach to transitional justice, which posits that accountability should never be bartered in order to arrive at 'peace', however defined. Certain parameters are set by international law on what options a state can take in a post-conflict setting, such as identifying and prosecuting individuals with criminal responsibility.22 War crimes, as well as torture, genocide, and crimes against humanity in both times of war and times of peace, are international crimes that have risen to the level of jus cogens, and therefore there exists a nonderogable obligation to prosecute or extradite the individuals responsible. No amnesties can be given. ${ }^{23}$ International law has thus been considered chiefly as effecting punishment or retributive justice only, in classic Nuremberg style. ${ }^{24}$ Exponents of the minimum accountability position make several claims for trials and retributive justice within the framework of transitional justice that go beyond the minimum requirements of prosecution; including that trials are the 'most effective insurance against future repression', ${ }^{25}$ bring solace to victims, ${ }^{26}$ serve as an education in

19 See Bassiouni M Cherif 'International Crimes: Jus Cogens and Obligatio Erga Omnes' (1996) 59 Law and Contemporary Problems 63 at 67. For a contrary view to Bassiouni from a realist, state-practice based viewpoint, see further Rubin Alfred P 'Actio Popularis, Jus Cogens and Offenses Erga Omnes?' (2001) 35(2) New England Law Review 265.

20 Barcelona Traction, Light and Power Co. Ltd (Spain v Belgium) (Second Phase) [1970] ICJ Rep 3 paras 33-4. See further Article 53 of the 1969 Vienna Convention on the Law of Treaties. Note also Bassiouni M Cherif (ed) 'Accountability for Violations of International Law' in Bassiouni above note 9 at fn 85.

21 Dinstein Yoram 'Human Rights in Armed Conflict: International Humanitarian Law' in Meron Theodore (ed) Human Rights in International Law: Legal and Policy Issues Vol II Clarendon Press Oxford 1984 p 350.

22 Paul van Zyl outlines five affirmative state obligations in international law, including the duty firstly to establish the fate of victims and secondly to identify perpetrators, thirdly to provide compensation to victims, fourthly to take affirmative measures to prevent non-repetition, and fifthly to prosecute and punish those found guilty. See van Zyl Paul 'Justice Without Punishment: Guaranteeing Human Rights in Transitional Societies' in Villa-Vicencio Charles and Verwoerd Wilhelm (eds) Looking Back Reaching Forward: Reflections on the Truth and Reconciliation Commission of South Africa UCT Press Cape Town 2000 p 42 at 49.

23 See further Saul Ben 'Was the Conflict in East Timor “Genocide” and Why Does it Matter?' (2001) 2(2) Melbourne Journal of International Law 477.

24 Bassiouni M Cherif (ed) 'Proposed guiding principles for combating impunity for international crimes'. in Post-Conflict Justice above note 9 at 257 .

25 Orentlicher above note 14 at 2537.

26 Aryeh Neier argues that punishment fulfills society's duty 'to honour and redeem the suffering of the individual victim'. See Orentlicher above note 14 at 2539. Note contra O'Connell James 'Gambling with the Psyche: Does Prosecuting Human Rights Violators Console their Victims?’ (2005) 46 Harvard International Law Journal 295 at 340. 
the rule of law, ${ }^{27}$ and bring about what Martin Luther King Junior would call the 'presence' of justice to a torn society. ${ }^{28}$

This legalist approach is beginning to embrace processes complementary to trials such as truth commissions, restorative justice elements within trials, interplay with traditional justice systems and a focus on longer-term issues such as the establishment of the rule of law. ${ }^{29}$ Overall though, according to the legalist view, the role of international law in any transitional justice process is to impose an obligation to punish. International law demands that certain crimes be punished and prescribes how this is to be done.

\subsection{The Realist Challenge}

A challenge to the legalist approach comes from a political realist position which see formalised justice as an impediment to peace, of use only as a bargaining chip to be bartered away for a better settlement. ${ }^{30}$ There are three key realist arguments against the legalist approach. Firstly, a realist would argue that the notion of legal accountability itself for participants in a conflict is fanciful and irrelevant. A realist may argue that the international community's decision-making with respect to the nature and extent of post-conflict justice needs is governed more often by geopolitical considerations than by notions of international law, ethics, or morals. This belief is often part of a broader theoretical position which claims that international law has no impact or place in international relations. ${ }^{31}$ Secondly, the realist argues that the legalist approach is destabilising and undemocratic. A realist favours the role of the leader (elected, or often the enlightened despot model) in deciding transitional justice issues, unfettered by any supranational considerations. ${ }^{32}$ Finally, realists argue that the legalist approach is applied selectively and usually only to assuage Western guilt, rather than in any consistent or objective manner.

27 Ruti Teitel notes that '[o]nly trials are thought to draw a bright line demarcating the normative shift from illegitimate to legitimate rule', but observes that trials have been rarely utilised in practice: above note 8 at 6 . See further Malamud Goti Jaime (ed) 'Trying Violations of Human Rights: The Dilemma of Transitional Democratic Governments' in State Crimes, Punishment or Pardon. Papers and Reports of the Conference, November 4-6 1988 Aspen Institute Wye Center Maryland $1989 \mathrm{p}$ 81-2.

28 Theodor Meron has stated ' $\mathrm{t}$ ] he great hope of tribunal advocates was that the individualization and decollectivisation of guilt... would help bring about peace and reconciliation': War Crimes Law Comes of Age: Essays Oxford University Press Oxford 1998 p 282.

29 Bassiouni claims that post-conflict or transitional justice strategies should be designed to complement the agenda of political stabilisation, while remaining committed to key human rights principles: Bassiouni M Cherif (ed) 'Introduction' in Post-Conflict Justice above note 9 at xv. Similarly, Hannah Arendt, in her correspondence with Karl Jaspers after Nuremberg, concluded that criminal prosecutions were a necessary but not sufficient response to state-sponsored atrocities: Hannah Arendt, Karl Jaspers: Correspondence, 1926-1969 Harcourt Brace Jovanovich New York 1992. Note discussion in Cobban Helena 'The Legacies of Collective Violence' (2002) 27(2) Boston Review 21.

30 Bassiouni M Cherif (ed) 'Introduction' in Post-Conflict Justice above note 9 at xv.

31 See further Scott Shirley 'International law as ideology: theorizing the relationship between international law and international politics' (1994) 5(1) European Journal of International Law 98.

32 Drumbl Mark A 'Pluralizing International Criminal Justice' (2005) 106 Michigan Law Review 1295 at 1309-11. 
The best known exponent of the realist position in relation to the first critique of legalism is US academic Samuel Huntington. He derides the idea that international law has made any contribution to transitional justice decisions.

In actual practice, what happened was little affected by moral and legal considerations. It was shaped almost exclusively by politics, by the nature of the democratisation process, and by the distribution of political power during and after the transition. ${ }^{33}$

This view is borne out to some extent by the research data. In a study of war crime trials, truth commissions, and amnesties pursued in civil wars that have ended since 1989, Jack Snyder and Leslie Vinjamuri find that states have tended to follow the dictates of 'pragmatism' while paying lip service to legalist arguments for justice. They also find that throughout the post-Cold War era, powerful states have been effective at pushing the development of the norm in directions that reinforce the authority of states and especially of liberal states. ${ }^{34}$

That is not only how it is, according to realists, but how it should be. This is the second realist critique of the legalist approach. Deals may need to be done to establish a lasting peace. A leader may need to give amnesties to promote security and should be able to do so based on the mandate (democratic or otherwise) that leader has. As the former president of Uruguay, Julio M. Sanguinetti, once stated, in relation to calls for justice for past atrocities in his country: 'What is more just, to consolidate the peace of a country where human rights are guaranteed today or to seek retroactive justice that could compromise that peace?'35

The third type of realist critique of the legalist approach criticises the implementation of the doctrine in practice, for example, that trials are slow and expensive, selective and political. Rather than spending millions to prosecute twelve individuals in the ad hoc International Criminal Tribunal for Rwanda, the same money could have been used more productively to rebuild the Rwandan national justice system and to encourage the development of a culture of compliance there. ${ }^{36}$ This critique can also take the form of arguing that every conflict is different and should be treated differently, which means that there are no agreed guidelines on minimum measures to be taken to avoid impunity. For example, Neil J Kritz advances the idea of primary and secondary audiences of transitional justice processes such as international tribunals. He asserts that international efforts can often be more reflective of Western guilt over tragic failures to intervene, such as the Rwanda tribunal — located in Arusha but administered by The Hague — than efforts

33 Huntington Samuel The Third Wave: Democratization in the Late Twentieth Century University of Oklahoma Press Norman 1991 pp 211-225. Huntington derives prescriptive 'guidelines for democratizers' at p 225. Henry Kissinger has also stated that the decision to punish past atrocities in newly democratizing states or to forget them is determined by politics, not any legal obligation to punish. See Vinjamuri Leslie and Snyder Jack 'Advocacy and Scholarship in the Study of International War Crime Tribunals and Transitional Justice' (2004) 7 Annual Review of Political Science 345 at 354.

34 The Bush Administration's emphasis on 'mixed' tribunals that emphasize local participation is an example of this trend. See Vinjamuri and Snyder as above at 354.

35 Quoted in Yudhawiranata Agung 'Opinion: RI needs truth commission’ The Jakarta Post 21 October 2003.

36 Eg Chesterman Simon Justice under international administration: Kosovo, East Timor and Afghanistan International Peace Academy New York 2002. 
that will reconstruct the rule of law in that state as well as avoid impunity. ${ }^{37}$ He notes that the primary audience should be the people of the society, who lived through and suffered in the conflict: victims, bystanders and perpetrators. The international community should be only a secondary audience, who might hope for jurisprudence, deterrence value and a better understanding of the conflict, which will aid early warning systems. ${ }^{38}$

The realist view of international law is that it is irrelevant or a veneer for political concerns, and that in a transitional justice context any insistence on the obligation to prosecute is antidemocratic and could also be destabilising. What if the leadership of the new democracy is not committed to the obligation to punish, but victims are? What if the geopolitical considerations are not sufficient for holding trials or the dynamic changes part way through the process? What if the trials are nothing more than a veneer? Impunity can still result from trials, if they are sufficiently flawed.

\subsection{Strategic Legalism}

The legalist and realist approaches are for the most part mutually exclusive. However, Snyder and Vinjamuri have identified a stream of 'strategic legalism' in the work of theorist Carlos Santiago Nino. ${ }^{39}$ Nino was highly critical of Argentine human rights groups, who, he says, 'held a Kantian view of punishment; even if society were on the verge of dissolution, it had the duty to punish the last offender'. ${ }^{40}$ But he also found that in relation to Argentina, trials could be 'great occasions for social deliberation and for collective examination of the moral values underlying public institutions', which can help break that power structure and invent a new, democratic society. ${ }^{41}$ In other words, trials might just be one more tool in a transitional justice toolkit, to be chosen only if the trials would promote some other type of social objective, not just the punishment of an individual criminal. This corresponds with Teitel's view of trials as useful in rebuilding the rule of law.

Strategic legalists might re-imagine the concept of impunity measures as consisting of immediate and mandatory trials, accept the limitations of law, and critique the idea of erga omnes and jus cogens norms themselves. New interdisciplinary studies of transitional justice challenge the normative basis of the obligation to punish, by asking whether or not courts actually help postatrocity societies to move beyond the multiple traumas inflicted during the era of atrocities and build a new society in which the violence of the past is not iterated. ${ }^{42}$ The argument is that trials of a few do not recognise that the scope of these crimes could not have been as large without the harnessing and the transformation of key societal institutions. In order to address the situation

37 Kritz Neil 'Progress and Humility: The Ongoing Search for Post-Conflict Justice' in Bassiouni above note 9 at 59 . See also Bassiouni M Cherif (ed) 'Introduction' in Post-Conflict Justice above note 9 at xv and xviii.

38 Kritz as above.

39 Vinjamuri and Snyder above note 33 at 361.

40 Nino Carlos Radical Evil on Trial Yale University Press New Haven 1996 p 112.

41 As above at 131.

42 Fletcher Laurel and Weinstein Harvey M 'Violence and Social Repair: Rethinking the Contribution of Justice to Reconciliation.' (2002) 24(3) Human Rights Quarterly 573. 
fully and provide a level of stability and order for the future of the society, these institutions, and the parameters within which the crimes occurred, need to be addressed. For example, trials cannot deal with unindicted perpetrators, states outside the area of conflict that may have contributed to the violence, or bystanders. ${ }^{43}$ This goes to the very heart of the legitimacy for creating individual responsibility for war crimes. ${ }^{44}$ It assumes that war time atrocities or 'extraordinary evil' can be dealt with by the methods we use to deal with 'ordinary' crime. ${ }^{45}$

Fletcher and Weinstein interviewed Bosnian judges and prosecutors and concluded that people's attitudes to accountability mechanisms are deeply affected by their proximity to the violence and their personalised experience of conflict. ${ }^{46}$ They conclude that a more 'ecological' response to social repair is necessary, addressing the damage mass violence causes at the community level. ${ }^{47}$ Some examples of ecological responses include truth commissions and traditional rituals, which have recently become sites of feminist examination. ${ }^{48}$ This idea is considered further in relation to reconceptualising the concept of a veteran.

The underlying debate is over what is the proper role of law, i.e., is political change a precondition to development of the rule of law or vice versa? ${ }^{49}$ This article argues for a new category of 'feminist strategic legalism' for those who are against impunity but are also sceptical of the claims made about criminal trials in a post-conflict setting in relation to gender concerns. What strategies are most conducive to transformative gender relations in a post-conflict setting?

\subsection{FEMINIST COUNTER-NARRATIVES: WHOSE TRANSITION? WHOSE JUSTICE?}

Generally speaking, the theoretical framework of transitional justice-outside the focus on the prosecution of sexual violence in criminal trials - has so far proved resistant to feminist analysis. In a groundbreaking article, Christine Bell and Catherine O'Rourke ask whether feminism even needs a theory of transitional justice. ${ }^{50}$ However, there have been some important insights that relate to the obligation to punish and the presence of justice. Thinking about gender and transitional justice yields some immediate questions, such as, has there been a transition at all? The research suggests that violence continues against women regardless of political context, in other words, that women may not experience a transition to non-violence because an end to

As above at 579 .

Aukerman above note 11 at 47 .

As above.

46 Fletcher and Weinstein above note 42.

As above at 574 .

48 Nesiah Vasuki Truth Commissions and Gender: Principles, Policies and Procedures Gender Justice Series International Centre for Transitional Justice New York 2006.

49 Teitel above note 8 at 6 .

50 Bell Christine and O'Rourke Catherine 'Does feminism need a theory of transitional justice?' (2007) 1 International Journal of Transitional Justice 23. 
formal hostilities is called. ${ }^{51}$ Gender-based violence in the both the conflict and post-conflict phase may get ignored or devalued because it is privatised. For example, sexual violence in armed conflict is conceived of as motivated by personal 'needs' of soldiers, unrelated to the conflict, even if perpetrated in places of public detention, or because it occurs in the private sphere such as domestic violence or home-based sexual slavery. ${ }^{52}$

The focus in international law on sexual violence seems to have blocked any consideration of other gender-based violations committed in wartime. For example, the dramatically increased levels of domestic violence that occurs in conflict; the failure to provide civilians with adequate access to shelter or protective equipment; the suffering of refugees and displaced persons who are forced to flee their communities; the lack of access to reproductive health assistance, and other socio-economic harms have all been substantially overlooked. ${ }^{53}$

This section focuses on the work feminist theory has done in deepening the understanding of women's experience of armed conflict, challenging both the legalist and realist positions. Most feminist approaches to the impact of international law in transitional justice processes have usually adopted the legalist approach advocating minimum accountability without further examination, and sought to make any trials resulting from the obligation to punish genderinclusive. ${ }^{54}$ The prominence given to prosecutorial remedies for gender violations of international humanitarian and human rights law is reproduced in the accountability provisions of UN Security Council Resolution 1325 (2000) on Women, Peace and Security. ${ }^{55}$ In addition to calling for an exclusion of amnesties, these provisions emphasise the responsibility of states to prosecute those responsible 'for genocide, crimes against humanity, and war crimes including those relating to sexual and other violence against women and girls', yet are silent on complementary forms of redress. ${ }^{56}$

Similarly, the Secretary-General's 2002 study on Women, Peace and Security ${ }^{57}$ and the Independent Experts' Assessment on the Impact of Armed Conflict on Women and Women's

51 Ní Aoláin Fionnuala D and Turner Catherine 'Gender, Truth and Transition' (2007) 16 UCLA Women's Law Journal 229 at 240.

52 Patricia Viseur-Sellers challenges a simplistic view of the public/private distinction in the case of sexual violence: 'Individual(s') liability for collective sexual violence' in Knop Karen (ed) Gender and Human Rights Oxford University Press Oxford 2004 and Engle Karen 'After the Collapse of the Public/Private Distinction: Strategizing Women's Rights' in Dallmeyer Dorinda (ed) Reconceiving Reality: Women and International Law American Society of International Law Washington 1993 p 143. See further Cockburn Cynthia The Space Between Us: Negotiating Gender and National Identities in Conflict Zed Books London 1998 and Stiglmayer Alexandra (ed) Mass Rape: The War Against Women in Bosnia-Herzegovina. University of Nebraska Press London 1993.

53 See eg Gardam Judith and Jarvis Michelle Women, Armed Conflict and International Law Kluwer Law International The Hague 2001 p 173 and Kapur Ratna 'The Tragedy of Victimization Rhetoric: Resurrecting the 'Native' Subject in International/Post-Colonial Feminist Legal Politics' (2002) 15 Harvard Human Rights Journal 1.

54 Carpenter Charli R 'Stirring Gender into the Mainstream: Feminism, Constructivism, and the Uses of Theory' (2003) 5(3) International Studies Review 287.

55 Millar Hayli above note 4 at 172.

56 Resolution on Women, Peace and Security SC Res 132555 UN SCOR (4213 th $\mathrm{mtg}$ ) UN Doc S/RES/1325 (2000) para 11.

57 See Women, Peace and Security, Study submitted by the Secretary-General pursuant to Security Council resolution 1325 (2000) (2002) paras 116-161, 343-345. See also Diane Otto's article in this issue. 
Role in Peace-building ${ }^{58}$ place greater emphasis on criminal prosecution than truth commissions, reparations or other forms of justice. The legalist approach assumes jus cogens norms are universal and gender-neutral, and therefore powerful advocacy tools for women. ${ }^{59}$ However, universality cannot be assumed. ${ }^{60}$ Rather, international law norms arguably have a primarily Western audience. ${ }^{61}$ Universality of jus cogens norms has also been questioned by feminist theorists who ask whether international criminal law been 'transformed' to meet the reality of women's experience of armed conflict, or only the experience of Western women, ${ }^{62}$ or is still fundamentally limited to the experience of elite men. ${ }^{63}$

One feminist reading of the legalist position could say that limiting the 'tradeability' of trials for a new state works in favour of women, who might be in a weak position as citizens after a conflict to 'trade' politically for a justice outcome. An example of this would be amnesty deals for ex-military struck at a peace negotiation where no women are present. International law is understood in this sense as a method of controlling the use and abuse of power. ${ }^{64}$

Realists could argue that international law is irrelevant and merely a rhetorical device, so that focusing on trials would be a waste of feminist energy and resources. Alternatively, they could argue that a decision by a new state to prosecute crimes, even including gender-based violence, may be destabilising to the fragile state. Women might then be the most vulnerable to any recurrence of violence. Neither view takes into account the idea of 'changing the curtains': that in fact women might still be experiencing violence on many levels and not be in a position to 'trade', all they have traded is one set of curtains for another. ${ }^{65}$ So a feminist strategic legalist view might see value in not trading trials for some other benefit in a post-conflict setting, but accept that there are gendered holes in the legalist view too.

The legalist position does not necessarily benefit women for three main reasons: lack of representation of women in decision-making structures within transitional justice mechanisms (or what Christine Bell and Catherine O'Rourke term 'visible exclusions'); ${ }^{66}$ the incomplete categorisation of acts that affect women as international crimes; and flawed prosecution strategies (which Bell and O'Rourke term 'conceptual exclusions'). ${ }^{67}$ These criticisms are predicated on making the legalist approach work better for women. However, Bell and O’Rourke also identify a

58 See Rehn Elisabeth and Sirleaf Johnson Ellen Women, War and Peace: The Independent Experts' Assessment on the Impact of Armed Conflict on Women and Women's Role in Peacebuilding UNIFEM New York 2002 pp 93-101.

59 Charlesworth Hilary and Chinkin Christine 'The Gender of Jus Cogens' (1993) 15 Human Rights Quarterly 63.

60 Kritz above note 37 at 59.

61 This is a debatable point. Western feminists have made use of the experiences/sufferings of 'the other' in their efforts to promote a gendered understanding of international law. In doing so Western feminists have interpreted the experiences of the other through a western cultural lens. However, this does not necessarily mean that non-western women do not appreciate or want the possible gains of the liberal international law framework.

62 Kapur above note 53 at 1.

63 Charlesworth Hilary and Chinkin Christine The Boundaries of International Law: A Feminist Analysis Manchester University Press Manchester 2000 pp 38-46.

64 Chinkin Christine and Charlesworth Hilary 'Building women into peace' (2006) 27(5) Third World Quarterly 937 at 946.

65 Or as Christine Bell and Catherine O'Rourke write 'women moving too easily from being 'pawns of war' to 'pawns of peace': above note 50 at 25 .

66 As above at 23 .

67 As above. 
'growing feminist unease' with the question of 'where is the feminism in transitional justice discourse?' ${ }^{68} \mathrm{I}$ argue the unease stems from acknowledging that the legalist approach might be insufficient to assist the attainment of material benefits for women in post-conflict settings, not to mention transformative societal reform on gender equality. New and creative strategies are required.

One feminist response to the obligation to punish under international law states that law is so resistant to women's lived experiences as to make trials not worth pursuing. ${ }^{69}$ This is partly because it is flawed in recognising the full experience of gender-based violence and because it does not 'redistribute' shame or any type of tangible benefit. ${ }^{70}$ Even if improvements were made on current practice in trials, scholars such as Karen Engle and Julie Mertus argue that better prosecution strategies may not solve the inherent problems facing women involved in international trials, ${ }^{71}$ and we should be critical of claims that international adjudication of wartime rape cases necessarily advances the interests of female survivors. ${ }^{72}$

The second important feminist counter-narrative relates to the categorisation function of international law. Judith Gardam argues that the project of categorisation of crimes should not be considered closed, that international humanitarian law does not adequately address the protection needs of women in armed conflict as it currently stands despite the admitted advances made, ${ }^{73}$ and violations must be perceived as sufficiently serious to constitute an international crime. ${ }^{74}$

The third important counter-narrative focuses on outcomes for women. Christine Bell and Catherine O'Rourke propose that feminist theorists should focus on how transitional justice debates help or hinder broader projects of securing material gains for women through transition. ${ }^{75}$ Similarly, Katherine M. Franke argues that transitional justice outcomes for women should be judged on whether they provide recognition and redistribution, as mentioned above. ${ }^{76}$ While transitional justice mechanisms can do both, Franke decides that they are mostly engaged with recognition-based justice projects and that this has come at a cost to the individual women involved, while the limited script offered to women casts them only as victims of sexual violence. ${ }^{77}$

In the next section I address the broader question as to why and how these limitations in the legal and social outcomes for women have occurred: are the deficiencies due to gaps in the law or are they structurally embedded-'hard-wired'-in the law itself? What if international law

\footnotetext{
68 As above.

69) See Engle above note 6 .

70 Franke Katherine M 'Gendered Subjects of Transitional Justice' (2006) 15(3) Columbia Journal of Gender and Law 813.

71 Engle above note 6.

72 See further Mertus Julie 'Shouting from the Bottom of the Well: The Impact of International Trials for Wartime Rape on Women's Agency' (2004) 6(1) International Feminist Journal of Politics 110.

73 Gardam and Jarvis above note 53 at 184.

74 See further Gardam Judith 'Women and Armed Conflict: The response of international law' in Durham and Gurd Listening to the Silences above note 4 at 1009.

75 Bell and O'Rourke above note 50 at 23.

76 Franke above note 70 at 813 .

77 As above.
} 
is not as relevant to transitional justice processes as international lawyers think it is? ${ }^{78}$ By employing feminist strategic legalism, I seek to assess three issues: the representation of women in transitional justice processes; the categorisation of crimes; and prosecution strategies and problems.

The above concerns might be addressed with the minimum accountability model. Trials can be made better, the participation and representation of women in transitional justice mechanisms could be mandated beyond a token gesture. Gaps in international criminal law with issues such as forced maternity could be successfully filled and implemented in the same manner as the issue of rape as a war crime. These strategies should be pursued vigorously by feminist legal scholars and practitioners, ${ }^{79}$ but that they are ultimately insufficient strategies. ${ }^{80}$ However, I suggest that the area of transitional justice that causes feminist unease because the issue of whether trials really achieve social repair is harder to assess. ${ }^{81}$

Bell and O'Rourke describe this unease as being about 'what exactly transitional justice is transiting "from" and "to"".82 they categorise conceptions of transitional justice as ordinary, liberalising or restorative, ${ }^{83}$ and argue that feminist theory should focus on a 'larger dream' of substantive and material justice for women. ${ }^{84} \mathrm{I}$ concur. If the violations against women in armed conflict arise from structural inequalities experienced in peace time, then processes are required which address structural discrimination in the society. Can individual criminal trials, or even communal truth commissions, separately or in combination contribute to this end-game?

Dealing with communal structures that engender violence is important when considering the transition from gender-persecution within a conflict zone to post-conflict justice. The postconflict phase is often seen as an opportunity for women's empowerment. As Sheila Meintjes has noted:

... women do gain from the shifts in gender relations during the war, they may lose their wartime gains in the cusp, in the period between war and peace. Thus the transition from war to peace emerges as a critical moment in the shifting terrain of gender power. ${ }^{85}$

Fionnuala Ni Aolain and Michael Hamilton suggest exactly the opposite: that what may appear to be a moment of opportunity in transitional societies can become what they term 'a moment of

78 See further Charlesworth Hilary 'Saddam Hussein: My part in his downfall' (2005) 27 Wisconsin International Law Journal 127-143.

79 There is a long-standing cultural feminist criticism of rights discourse as aggressive or shrill, obsessed with individualism and not an ethic of care, symbolic only, prone to counter-rights claims. See Carol Smart (ed) 'The Problem of Rights' in Feminism and the power of law Taylor and Francis London and New York 1989 p 138 at 159.

80 Criticism of trials could flow naturally from the gap between law and justice, inevitable because rights have a 'symbolic valance' that can never be realised by the laws on the books: Pahuja Sundhya 'Rights as regulation: The integration of development and human rights' paper presented at the 15 th Annual ANZSIL Conference, Canberra, 29 June 2007.

81 Fletcher and Weinstein above note 42 at 573

82 Bell and O'Rourke above note 50 at 35 .

83 As above at 36-44.

84 As above at 44 .

85 Meintjes Sheila 'War and Post-War Shifts in Gender Relations' in Meintjes S, Turshen M and Pillay A (eds) The Aftermath: Women in Post-Conflict Transition Zed Press London 2001 p 64. 
retrenchment', partly due to Western interventions that entrench the operation of the public/private divide in transitional states. ${ }^{86}$ The sexual stereotyping of women in transitional justice processes has even been linked to the increased vulnerability of women in transitional societies to sexual trafficking and slavery. ${ }^{87}$ This also has ramifications for 'post-conflict' economic policies:

... not only is 'post-conflict' a misnomer for women, so too may be reconstruction, reintegration and rehabilitation. These concepts all assume an element of going back, restoring people to a position or capacity that previously existed. But this is not necessarily what women seek. The goal is rather societal transformation, that is, not restored dependence and subordination but rather an enhanced social position that accords full citizenship, social justice and empowerment based upon respect for standards of women's human dignity and human rights that may never have previously existed. On the other hand, going back may be precisely what is wanted and it should not be assumed that because women have been subordinated by conflict that they have no agency or are unable to formulate their own agendas. ${ }^{8}$

Women may be experiencing a mere changing of the curtains from transitional justice processes, and the new curtains may even be cut from the same cloth. Franke's conception is that in the first dynamic stages of transition, different narratives of the past are battling for dominance, including masculinised and feminised narratives of the conflict and the future. She presents the idea that the deaths or absence of many men can create a feminised society which then can be confronted by a strong 'remasculinisation' of culture, of which domestic violence is a part. ${ }^{89}$

\subsection{FEMINIST STRATEgIC LEgALISM APPLIED}

\subsection{Whose Truth? Representation of Women in Transitional Justice Processes}

Although the obligation to punish is non-discriminatory, it does not rely on democratic acceptance and does not address the issue of representation of women in transitional justice mechanisms..$^{90}$ Representation is used here in both senses of the term — numerical and actual

86 Ni Aoláin Fionnuala and Hamilton Michael 'Gender and the Rule of Law in Transitional Societies' Minnesota Legal Studies Research Paper No. 09-12; Transitional Justice Institute Research Paper No. 09-02 March 2009 p 102.

87 Ní Aoláin and Turner above note 51 at 262

88 Chinkin Christine (Consultant to the Division for the Advancement of Women) Peace Agreements as a Means for Promoting Gender Equality and Ensuring Participation of Women EGM/PEACE/2003/BP.1 31 October 2003 United Nations Division for the Advancement of Women (DAW) Expert Group Meeting on 'Peace agreements as a means for promoting gender equality and ensuring participation of women - A framework of model provisions' 10-13 November 2003 Ottawa Canada $\mathrm{p} 9$.

89 As above at 824 .

90 Buss Doris 'Women at the Borders: Rape and Nationalism in International Law' (1998) 6(2) Feminist Legal Studies 171 and Chinkin Christine 'Symposium - The Yugoslav Crisis: New International Law Issues, Rape and Sexual Abuse of Women in International Law' (1994) 5 European Journal of International Law 326. 
participation by women and the stories of women. Women are unlikely to be represented in transitional justice mechanisms if there is little 'gender-mapping' of the conflict and women are excluded from the peace negotiations and agreements. ${ }^{91}$ Even democratic structures might not automatically mean that women represent other women or that all women's views are wellrepresented. ${ }^{92}$ 'Gender-mapping' a conflict refers to assessment and documentation of genderbased violations during a conflict. ${ }^{93}$ Lack of documentation of gender-based violations has consequences for the proper prosecution of those offences. An all-female team of investigators conducted the first rape investigation in time of conflict for the Independent Commission for Former Yugoslavia (ICTY), and the evidence was provided to the Office of the Prosecutor of the ICTY ${ }^{94}$ Christine Chinkin argues that 'mapping' a conflict is crucial to drafting an effective peace agreement. ${ }^{95}$ It is important in its own right, and also important to establish factual bases for any proposed humanitarian intervention by the international community, to provide objective evidence of the role and status of women and any changes in that society. Moreover, transitional justice outcomes that benefit women are unattainable unless the full realities of their lives before and after the conflict are understood.

This silence both reflects and helps perpetuate a situation in which women are not consulted and do not participate adequately in transitional justice processes. The requirement for the equal representation of women in public life is based on the principle of non-discrimination in human rights law and the idea that politics is constitutive for the processes of society as a whole and not simply a mechanical 'reflection' of social and economic interests. ${ }^{96}$ Therefore, the exclusion of women and non-integration of a gender perspective in transitional justice processes reinforces existing power asymmetries between women and men; these processes are thus less likely to contribute to sustainable peacebuilding. ${ }^{97}$

Part of the answer is to pursue strategies which facilitate the participation of women in mechanisms designed around the obligation to punish, and also to those designed to promote truth-telling. This can lead to an 'add women and stir' approach..$^{98}$ Alternative to trials, such as truth commissions, unofficial tribunals and traditional justice practices, deserve further attention. The participation of women in the less formal mechanisms is still partial and may still be predicated on the same problematic foundations as trials, such as the 'truth' being what happened

91 Bell and O'Rourke above note 50 at 34.

92 Chinkin above note 88.

93 As above.

94 Bassiouni M Cherif (ed) 'The United Nations Commission of Experts on the Former Yugoslavia' in Post-Conflict Justice above note 9 at 449 .

95 Chinkin above note 88 at 9. See also the work of Catherine Bell.

96 Schofield Toni and Bacchi Carol 'Reinventing Gender Equality and the Political' paper presented at University of Sydney 29-30 September 2005. See also the Commonwealth Secretariat Gender equality and the judiciary: using international standards to promote the human rights of women and the girl child Commonwealth Secretariat London 1999.

97 See eg Francis Diana 'Culture, Power Asymmetries and Gender in Conflict Transformation' in Berghof Handbook for Conflict Transformation Berghof Research Centre for Constructive Conflict Management 2001 p 9.

98 Charlesworth and Chinkin above note 63 at 310-12. 
to men, and the only truth about women being their experience of sexual violence. ${ }^{99}$ For example, in a truth commission context, women often tell men's stories of violations (their husbands or sons) to commission hearings rather than their own. ${ }^{100}$ The most visible female activists in transitional contexts have often been mothers of the disappeared, or widows. ${ }^{101}$ It follows that truth commissions may portray the violations experienced by women as a relatively small percentage of the total violations reported to the commission.

Gender bias has been identified in the truth-telling function of truth commissions. Firstly, a gender dimension is lacking when examining the range of harms in a conflict; ${ }^{102}$ secondly, there is a focus only on sexual violence when harms against women are considered; ${ }^{103}$ and thirdly, 'ordinary' or routine violence is omitted, especially socio-economic harm experienced by women in conflict due to their gendered roles. ${ }^{104}$ The failure of truth commissions to fully integrate women's experiences is troubling on a practical level as it may restrict women's entitlement to additional forms of legal redress, ${ }^{105}$ but also on a symbolic level because it leads to a distorted historical record of 'truth'. ${ }^{106}$

On the other hand, due to their mandate to present an overall narrative of the conflict, truth commissions may be better at finding patterns and structural gender problems. The Sierra Leone Truth Commission sought to answer the question in its final report as to "why extraordinary violence was perpetrated against women?'107 It found that the low status of women, their lack of economic self-sufficiency and the belief of men that women were their property were all part of the answer. ${ }^{108}$

This is valuable, but truth commissions do not address impunity directly, and this may be important to women in transitional justice settings being asked to live with the perpetrators of crimes against them. Much depends on how the final report and recommendations are dealt with by the particular society, and how the process is complementary to any serious crimes process. Truth commissions may not provide any material benefit to women's lives unless combined with a gender-sensitive reparations programme.

99 See further Rosser Emily 'Depoliticised Speech and Sexed Visibility: Women, Gender and Sexual Violence in the 1999 Guatemalan Comisión para el Esclarecimiento Histórico Report' (2007) 3 International Journal of Transitional Justice 391.

100 Millar Hayli above note 4 at 176.

101 As above at 186.

102 Ní Aoláin and Turner above note 51 at 260.

103 As above at 260-262.

104 As above at 262-265.

105 Millar Hayli above note 4 at 186.

106 Ní Aoláin and Turner above note 51 at 273.

107 Sierra Leone's Truth and Reconciliation Commission Witness to Truth: Report of the Sierra Leone Truth and Reconciliation Commission 2004 p 87.

108 As above. 


\subsection{Categorisation of Crimes: Whose Crimes?}

Jan Jindy Pettman asked in 1996 ' $[\mathrm{w}]$ hat has it meant to displace sex onto women, and to see sex as not political?'109 Chilla Bulbeck replied '[i]t has meant drawing a sharp line of visibility and invisibility between military violence and domestic violence, thus obscuring useful ways to understand intra-state or intermediate forms of patterned sexual violence, for example, war rape'. ${ }^{110}$ There have now been significant achievements by feminist lawyers in the project of categorising some forms of gendered behaviour in conflict as international crimes. ${ }^{111}$ Feminists have concentrated on this strategy because the categorisation of some behaviours as international crimes has a critical influence on Security Council decisions to intervene, the triggering of the obligation to punish, and a resulting prosecution strategy.

On this point of recognising patterned sexual violence, there has been considerable progress. Article $7(\mathrm{~g})$ of the Rome Statute (1998) explicitly enumerates rape as a crime against humanity. The Security Council unanimously adopted Resolution 1325 (2000) on the topic of 'Women, Peace and Security' urging the Secretary-General to carry out a study on the impact of armed conflict on women and girls, and the role of women in peace-building. Prosecutions for gender-related crimes in international criminal law have also been hailed as revolutionary. Both the ad hoc tribunals for Yugoslavia and Rwanda, as well as the Sierra Leone Special Court have successfully indicted, prosecuted and convicted defendants for gender-based crimes, including rape as a crime against humanity and an element of genocide in the Akayesu case before the ICTR, ${ }^{112}$ and the Celebici, Furundrija and Kunarac cases relating to rape as torture, sexual slavery and sexual acts as inhumane treatment before the ICTY. ${ }^{113}$ There have been significant decisions by regional human rights courts, such as Mejia Egocheaga v. Peru in the Inter-American Commission of Human Rights, which accepted rape as torture. ${ }^{114}$

Why then do feminist international lawyers continue to argue that law, including international law, is gendered and resistant to attempts to transform it into a legal system that can properly deal with women's experience? ${ }^{115}$ Feminist lawyers claim that generally the law of armed conflict has historically set up the male combatant's experience in conflict as the standard and thereby has misunderstood or left women's experience of conflict unregulated in the 'private' sphere. ${ }^{116}$ In this light, the breakthroughs above could be seen as exceptional. Much of the progress in the feminist categorisation project has been made by reinterpreting existing

109 Pettman above note 5 at 8.

110 Bulbeck Chilla 'Book Reviews' (2005) 7(1) International Feminist Journal of Politics 157 at 158.

111 See further Campbell Kirsten 'The Gender of Transitional Justice: Law, Sexual Violence and the International Criminal Tribunal for the Former Yugoslavia' (2007) 3 International Journal of Transitional Justice 411.

112 Prosecutor v Jean-Paul Akayesu 2 September 1999 ICTR-96-4-T.

113 Prosecutor v Dragoljub Kunarac, Radomir Kovac and Zoran Vukovic Judgement Case No. IT-96-23/1-T 22 February 2001; Prosecutor v Anto Furundrija 10 December 1998 ICTY-95-17/1-T.

114 (1996) 1 Butterworths Human Rights Cases 229. See Charlesworth and Chinkin above note 63 at 330-2.

115 As above.

116 As above. See also Naffine Ngaire 'Sexing the Subject (of Law)' in Thornton Margaret (ed) Public and Private: Feminist Legal Debates Oxford University Press Oxford 1995 pp 18, 20 and 32; and MacKinnon Catherine Feminism Unmodified: Discourses on Life and Law Harvard University Press Boston 1987. 
international violations through a gendered lens. ${ }^{117}$ For example, domestic violence can be prosecuted as torture or rape as a crime against humanity ${ }^{118}$ as opposed to transcending or reinventing the existing template of male experience. The requirement that an individual act be part of a systematic or widespread pattern/policy is difficult to fit into the traditional conceptualisation of domestic violence in either conflict or post-conflict settings. A reconceptualisation of how those requirements are interpreted would be required which does not yet exist in the case law, or in domestic legal systems.

There are still significant gender gaps in international humanitarian law and corresponding gaps in gender theory which affect transitional justice mechanisms. For example, the issues of forced maternity and domestic violence are key transitional justice issues that raise important gender questions, but there is little recognition of either of these problems in their own right under international law. Theoretical explanations of their impact on women in a post-conflict setting are also thin. Forced maternity is a particularly complex phenomenon, perhaps because it straddles states of war and peace, and there is no parallel offence which can happen to a man. ${ }^{119}$ Forced maternity raises the constant question of whether to emphasise the 'sameness' or 'difference' of women's experience to men's. ${ }^{120}$

The continuance of the categorisation project therefore has merit, but Judith Gardam has cogently argued that the project of moving crimes which happen to women in war into the public sphere may not rectify the limitations of the law. ${ }^{121}$ One important limitation, as noted in relation to truth commissions above, is that international law tends to emphasise women's sexual and reproductive identities and harms inflicted by opposing forces. ${ }^{122}$ The International Committee of the Red Cross (ICRC) also made this point when it released a comprehensive study in 2001 titled 'Women Facing War'. ${ }^{123}$ The ICRC found that women are not innately vulnerable, but can be made vulnerable since they are seen as 'symbolic' bearers of their racial, cultural or religious identity, as well as being the producers of future generations. ${ }^{124}$ Other factors that render women vulnerable are specific skills, social status and economic situation, an intersection of distinguishing features.

Women are not exclusively the victims, the caregivers or the passive supporters of men in times of armed conflict. ${ }^{125}$ The reality of modern conflict is that women's roles also include being involved as members in armed forces and perpetrators of various forms of violence. It is this sort of complexity and recognition of intersectionality in gender identity that should be reflected in legal responses and the categorisation of crimes.

117 Chinkin above note 90 at 326.

118 See eg Edwards Alice 'The "Feminizing" of Torture under International Human Rights Law' (2006) 19(2) Leiden Journal of International Law 349.

119 My thanks to Dianne Otto for prompting this insight.

120 See eg MacKinnon Catharine Are Women Human? And other international dialogues Harvard University Press Cambridge 2006.

121 See further Gardam above note 74.

122 Pettman above note 5 at 100.

123 International Committee of the Red Cross (ICRC) Woman Facing War ICRC Geneva 2001 pp 8-9.

124 As above at 10 .

125 Durham and Gurd 'Preface' in Listening to the Silences above note 4 at 3. 


\subsection{Prosecution Strategies and Problems: Whose Justice?}

In this section I set out feminist challenges to prosecution of international crimes. Even if women are represented in a meaningful way, or if international law itself can be made inclusive of women's experiences, it does not follow automatically that the implementation of the law will be gender-sensitive, or pursued 'with the same fervour as are the war crimes which happen routinely to men'. ${ }^{126}$

Due to precedents such as Akayesu or the ICTY cases, feminist lawyers assume that progress in jurisprudence will continue that trials will be proceeding from a better base of gendersensitive legislation, procedural rules and jurisprudence. This assumption may be ill-founded. For example, crimes against humanity are required to be wide-spread and systematic, and as Charlesworth and Chinkin point out, 'although the rapes and sexual violence in the former Yugoslavia have been perceived in such terms, this may not always be the case. There is a tendency to regard the sexual abuse in the former Yugoslavia as exceptional and not as a regularly occurring part of armed conflict.' 127 They note that the UN's 'fact-finding' in Rwanda in 1994 did not detect systematic sexual violence against women until nine months after the genocide, 'when women began to give birth in unprecedented numbers'. ${ }^{128}$

There are a series of practical problems with prosecution strategies in attempts to achieving justice for women. Firstly, successful prosecutions require witnesses. A recurring problem for transitional justice processes is significant under-reporting of gender-persecution. Due to the trauma of the victim, the social stigma attached to rape and fear of ostracism from her family and inadequate concern of authorities, women are less likely to seek redress by reporting rape to the authorities, increasing the likelihood of impunity for a persecutor. ${ }^{129}$ Many serious acts of genderbased violence, including domestic violence, can have the psychological effect of torture. Torture, as a crime, has a lasting effect on its victims, that of silencing and alienating them from communal support. The psychological harm created by torture can have disproportionately negative effects on women, already disadvantaged in power structures. ${ }^{130}$ The purpose of a criminal trial in a transitional justice context is to prosecute and punish the major war criminals for violations of international law, thus a war crimes trial can 'only do so much'. ${ }^{131}$

The second practical problem with trials is that the process of giving testimony in trials or to a lesser extent other types of public proceedings may only serve to re-traumatise women. Nicola Henry has analysed the experience of women giving evidence of gender-based violence in international war crimes trials. Henry notes that war crimes trials might have an inherently

\footnotetext{
126 Copelon Rhonda 'Women and war crimes' (1995) 69 St John's Law Review 61 at 65.

127 Charlesworth and Chinkin above note 63 at 333.

128 As above at 219.

129 Rehn and Sirleaf above note 58 at 99.

130 Note Opotow Susan 'Psychology of Impunity and Injustice: Implications for Societal Reconciliation' in Bassiouni above note 9 at 206

131 Mertus Julie 'Truth in a box: the limits of justice through judicial mechanisms' in Amadiume I and An-Na'im A (eds) The Politics of Memory: Truth, Healing and Social Justice Zed Books New York 2000.
} 
counter-narrative effect', ${ }^{132}$ despite the best efforts of investigators and prosecutors. ${ }^{133}$ The physical and psychological wounds as a consequence of rape and sexual abuse are often not part of accepted rape testimonies, as emotions have no place in the courtroom, ${ }^{134}$ if prosecutors or judges want to deal with sexual violence issues at all. ${ }^{135}$

The nature of defence strategy is to discredit the evidence of the witness or prove consent, which may exacerbate the devaluation of raped women who have come to testify, even in an international tribunals, where the sexual violence alleged is often systematic. The possibility of retraumatisation is a highly likely response within this context, as we have seen so often in domestic trials. Inevitably, the reconstruction of the story will entail reliving of the traumatic event and may induce retraumatisation. ${ }^{136}$

Thirdly, a war crimes trial may not in fact be the appropriate context for sexual violence survivors to reconstruct their stories and thus recover from their traumatic experiences. Even if not retraumatised, victims of sexual violence, if they are actually chosen to give testimony at a trial, only get to tell a piece of their story. Further, those experiences remain cloaked in secrecy given that, out of necessity for their protection and safety, the court sessions are often in private. There is no necessary link between publicity and healing. There have also been reports of the ostracism of women on their return to their communities. ${ }^{137}$

Healing may not then result from a trial process. On the other hand, testifying at public proceedings such as a trial is potentially an empowering process for survivors given that it constitutes a measure of justice due to the legal weight given to their words. ${ }^{138}$ This may be an advantage of truth commissions, although Ní Aoláin and Turner warn that the informality and flexibility of the truth commission mechanism may make them more susceptible to discriminatory factors. ${ }^{139}$ Even in the rare case where every care is taken of the witness, progress in jurisprudence

132 In other words, witnesses are prevented from telling their stories in their own words, due to interrogation from opposing counsel.

133 Henry Nicola 'Secrecy, Silence and Sexual Violence in International Criminal Proceedings' paper presented at the Activating Human Rights and Diversity, Byron Bay, 1-4 July 2003.

134 Henry Nicola Disclosure, Sexual violence and international jurisprudence: a therapeutic approach PhD Dissertation University of Melbourne 2005.

135 Staggs Kelsall Michelle and Stepakoff Shanee "When We Wanted to Talk About Rape": Silencing Sexual Violence at the Special Court for Sierra Leone' (2007) 3 International Journal of Transitional Justice 355.

136 Herman Judith Trauma and Recovery: The Aftermath of Violence from Domestic Abuse to Political Terror Basic Books New York 1992.

137 See the Kosovo Rehabilitation Centre for Torture Victims (KRCT) study concerning witnesses from the Kosovo population regarding the possibility of their retraumatisation during the trial process of Milosevic in The Hague: Sci Enver Çesko Melita Kallaba Vjosa Devaja Agim Selimi Shaban Jashari and Merita Emini Study with the Clients Treated at the KRCT, from the Witnesses and the Kosovo Population Regarding the Possibility of their Re-Traumatization During the Trial Process of Milosevic in Hague. Kosovo Rehabilitation Centre for Torture Victims 2002 pp 1-9.

138 Stanley Elizabeth Torture, Truth and Justice: The Case of Timor Leste Routledge New York and London 2009. For these reasons, Rosalind Dixon has proposed an international civil tribunal for war crimes against women: 'Rape as a crime in international humanitarian law: where to from here?’ (2002) 13(3) European Journal of International Law 697-719.

139 Ní Aoláin and Turner above note 51 at 233. 
comes at a great personal cost to the women involved. As Franke puts it, war crimes trials operate best on the 'wholesale' not 'retail' level. ${ }^{140}$

Fourthly, material benefits in the form of financial compensation for women who participate in trials and truth commissions may not be forthcoming. The legal consequences of the supranational criminal law system (sentencing and reparations) are increasingly being examined with the situation of survivors of gender-based violence in mind. This is a welcome development, ${ }^{141}$ but there is still a lack of long term financial assistance available through the trial process. These problems would confirm Fletcher and Weinstein's argument that legalist solutions may not promote social repair, even for the individual women directly involved.

\subsection{POSSIBILITIES FOR REINVENTION: WOMEN AS VETERANS}

Katherine M Franke has argued that the most useful theoretical framework for addressing the benefits of transitional justice for women is that which considers both recognition of individual experience and redistribution of shame and the benefits of peace. ${ }^{142}$ Even where recognition is achieved (or partially achieved for the reasons noted above) by the obligation to punish, redistribution of shame and basic livelihoods affected by conflict has not been achieved. ${ }^{143}$ Feminist theory should identify some creative alternatives that seek to provide justice for both the individual and communal harms women experienced in war and peace, to fulfil the call for women to be treated as heroes. ${ }^{144} \mathrm{I}$ argue above that moving gender issues from the private to the public sphere may not lead to a material benefit for survivors of gender violence from a transitional justice process, even those which focus on restorative justice measures. In other words, breaking down the public/private distinction may not be a sufficient strategy.

Improving the material position of women and pursuing strategies that make trials better will not rectify the core problem of providing material long-term assistance to survivors of the conflict and improving their status in society. A perennial question facing feminists is how to recognise the scope of the harms visited upon women without characterising them as victims. In particular, women in a transitional justice process need to be offered a script which does not cast them only as victims of sexual violence. ${ }^{145}$

I therefore propose that female non-combatant survivors of armed conflicts should be accorded veteran status. This leads to the question of the criteria for inclusion. Should it be all women who lived through armed conflict, or a sub-category of women who would qualify because they experienced violations or participated in resistance in some manner? Should non-

\footnotetext{
140 Franke above note 70 at 820 .

141 De Brouwer Anne-Marie ALM Supranational Criminal Prosecution of Sexual Violence: The ICC and the Practice of the ICTY and the ICTR Antwerpen Intersentia 2005.

142 Franke above note 70 at 823.

143 As above at 814.

144 Second Women's Congress National Action Plan July 2004 Dili.

145 Franke above note 70 at 823.
} 
combatant men be included on the same basis? It could be argued that there are other ways for recognising women's suffering than bringing them into the combatant/veteran framework.

However, such a move would take away an exclusive focus on sexual harms, and refocus attention on violations of women's economic, social and cultural rights during and after armed conflict. ${ }^{146}$ Moreover, such a measure might focus on patterns of behaviour that surface the gendered dimensions of violence occurring to men in armed conflict, especially non-combatant men. ${ }^{147}$ As Franke puts it:

The reduction of gender to the sexual and the ignorance of how men can suffer gendered violence is, to be most generous, a form of overcompensation for the years of ignoring women's place in humanitarian law. ${ }^{148}$

Since the two World Wars, the concept of a veteran has come to mean many different things in different contexts, ${ }^{149}$ but at the core of the term it has three benefits. A veteran receives maintenance and entitlements from the state for life. The veteran has a certain status and standing when it comes to transitional justice decisions. If not always consulted, veterans are at least considered central to the process. Society is called upon to reflect on the contribution to the overall welfare of society that a veteran has made. ${ }^{150}$ The idea of veteran as fighter could be displaced and replaced with the idea of veteran as survivor.

Feminist international relations scholars alert us to another benefit of thinking of women survivors as veterans as a transitional justice process. In a post-conflict context, the historical record of the conflict produced by trials and truth commissions is also a nationalist narrative, which employs deeply gendered discourse. Pettman notes that the nation is often called up in familial language - motherland, kin, blood, home-language that is strangely different from the Realist representations of power politics and rational self-interest. In a complex play, the state is often gendered male and the nation female'. ${ }^{151}$ The nation is often represented as a woman under threat of violation; ${ }^{152}$ and sexual harms can be directed at eliminating the integrity of the individual woman's community. ${ }^{153}$ The 'complex politics between actual women's bodies and the dangers they experience in wars and identity conflicts on the one hand, and nationalist discourses

146 Ní Aoláin and Turner above note 51 at 239.

147 Carpenter R Charli Innocent Women and Children': Gender, Norms and the Protection of Civilians Ashgate Hampshire 2006 pp $2-$ 3. See also Hamber Brandon 'Masculinity and Transitional Justice: An Exploratory Essay' (2007) 3 International Journal of Transitional Justice 375.

148 Franke above note 70 at 822 .

149 Sturken Marita 'The Wall, the Screen, and the Image: The Vietnam Veterans Memorial' (1991) 35 Representations (Special Issue: Monumental Histories) 118. Most of the literature around veterans is medical in nature or historical description. See eg Friedman Matthew J 'Veterans' Mental Health in the Wake of War' (2005) 352(13) New England Journal of Medicine 1287.

150 Chinkin and Charlesworth above note 64 at 946.

151 Pettman above note 5 at 49 .

152 As above.

153 Ní Aoláin Fionnuala D 'Rethinking the Concept of Harm and Legal Categorisations of Sexual Violence During War' (2000)1(2) Theoretical Inquiries in Law 1. 
using representations of women's bodies to mark national or communal bodies on the other'154 is often very clear.

Constructing women as wartime veterans might therefore have the effect of redistributing shame and changing the nationalist discourse. It may at least provide a language and a framework - a new script - which may be validating to the survivors themselves. In addition, a step such as this would go a long way toward meeting some of the economic, as well as social needs of women and their children. It may also focus attention on women as development actors. Money from the international community earmarked for victim funds could become veterans' programs. ${ }^{155}$

\subsection{CONCLUSION}

For feminist international lawyers who accept a role for international law in post-conflict societies, there is a need to move beyond improving the content and application of international criminal law in trials to a broader quest for justice for women in post-conflict states, better informed by realist critiques. Gaining breakthrough precedents in a courtroom is an important endeavour, but it should not be the sole or even the primary task, particularly in an in-country context where the trials themselves may be badly designed or executed. To this end, this article poses what Cynthia Enloe terms the radical feminist question 'what if?'156 What if lawyers were more focused on the right political conditions to hold trials? What would need to happen for the curtains to be ripped down and a new view of the world exposed?

The benefit of the legalist model of transitional justice for women lies in the fact that a new state or the UN cannot 'trade' the rights of the least powerful for the benefit of the most powerful or vocal in the new state. However, this model runs the risk of being imposed without any consultation with the affected community, including women, thus limiting the possibilities of democratic participation or the incorporation of indigenous justice mechanisms. At the same time, the benefits of truth commissions and informal justice mechanisms may be oversold. ${ }^{157}$ Legal responses per se need to be carefully and modestly evaluated for their capacity to deal with the intense dislocation, the complete destruction, which conflict inflicts on humanity. ${ }^{158}$

154 Pettman above note 5 at 51.

$155 \mathrm{Eg}$ the International Criminal Court Trust Fund for Victims or the UNIFEM Trust Fund in Support of Actions to Eliminate Violence Against Women.

156 Enloe Cynthia Bananas, Beaches and Bases: Making Sense of Feminist Politics University of California Press Berkley 1989 p 3.

157 CM de Vos 'What price truth? South Africa's Truth and Reconciliation Commission in Critical Perspective' (2002) 29 Politikon 209 at 225. See also Sarkin Jeremy and Daly Erin 'Too Many Questions, Too Few Answers: Reconciliation in Transitional Societies' (2004) 35 Colombia Human Rights Law Review 661 at 664; Brody Reed 'Justice: The First Casualty of Truth' (2002) 272 The Nation 25 at 28-9 and Kritz Neil J 'Book Review: War Crimes, Brutality, Genocide, Terror and the Struggle for Justice’ (1999) 93 American Journal of International Law 98.

158 Minow above note 8 at 5 . For another account of the limitations of legal responses see Nino above note 40 at 104-85. See further Robinson Jennifer Dealing with Memoria Passionis in Papua Honours Dissertation Australian National University 2005. 
As a bare minimum, any international interventions in transitional justice decisions, such as the setting up of hybrid tribunals or truth commissions, should seek to do no harm to women. The international community should be inclusive of women's experiences of the conflict and post-conflict periods in anything it funds or recommends in a transitional society. I suggest that it might be better to pursue non-legal methods of attaining material benefit than to encourage women to participate in flawed trials in a post-conflict transitional period.

This is an area where the realist arguments expounded earlier in the paper deserve engagement. Narrow legalist scholarship in this area may be leading to failures of imagination in responding to the complexities of transitional justice processes. While I reject the realist acceptance of impunity for political expediency, international lawyers cannot afford to ignore the political pressures new states face when making transitional justice decisions. Feminist lawyers cannot ignore the possibility that trials can do damage, or just change the curtains. International lawyers need to move beyond the concept of 'trial as end-game', and be more responsive to both the political realities faced by a new state and the situation of women in that state when advocating and designing particular mechanisms. Legalist scholarship has centred on the appropriate forum for prosecuting war criminals and the implications of war crime tribunals for the further development of international humanitarian law and, more generally, of the international criminal justice system. The risk is that if the trials are not well-designed and wellexecuted, they may fail and undermine the establishment of the rule of law in the longer peacebuilding effort.

Much depends on the right conditions for holding trials. If those hearings may serve only to construct women as victims of sexual violence, retraumatise them and further stigmatise them at a time when it is most important that women build trust in the rule of law to protect them, then they should not be pursued. Truth commissions and other ritualised processes may do better at providing some sort of social repair for communities. Then there may need to be additional measures to ensure women's long term economic rights and protections are addressed.

The minimum accountability model is currently presented or assumed to be gender-neutral in its effects. Pursuing legal responses in the wrong circumstances may be worse for women that doing nothing at all in the early periods of transition. In the absence of the requisite political will at both the domestic and international level, transitional justice mechanisms can be manipulated or rendered impotent, whilst creating false expectations, waylaying the efforts of human rights advocates and costing millions of donor dollars. ${ }^{159}$

A feminist strategic legalist approach would focus on gaining the full participation of women in peace negotiations and key decisions about transitional justice processes and the development of a justice sector, and preserving evidence and acquiring data in relation to international and domestic gender crimes for the day when fair trials can be held. Efforts could be focused on keeping women safe from post-conflict spikes in domestic violence and improving basic standards of living through interventions based on a rights-based approach to

159 Pigou Piers Crying Without Tears: In Pursuit of Justice and Reconciliation in East Timor Leste: Community Perspectives and Expectations International Center for Transitional Justice New York 2003. 
development. ${ }^{160}$ Advocacy for access to a victims fund or reparations that did not rely on a lengthy legal process could be beneficial.

The formal ending of violence does not necessarily mean the achievement of peace, rather it provides a 'new set of opportunities that can be grasped or thrown away'. ${ }^{161}$ Law in a transitional period might hold an 'independent potential for effecting transformative politics' and 'liberalising' change. ${ }^{162}$ On the other hand, in the context of the societal breakdown caused by armed conflict, feminist scholars may be asking international law to engage in too much 'heavylifting. ${ }^{163}$ If transitional justice represents theory and praxis in a liminal zone between international relations and international law, both of which have proved resistant to feminist analysis, why are many feminists so confident that transitional justice represents an opportunity for transformative change? This may be an 'article of faith' held by feminist lawyers which needs to be revisited, or it might even represent a distraction from the main game of achieving justice for women in a broader sense.

The concept that international law should be 'transformative' is central to a feminist methodology, but only in the full acknowledgement of the limitations and problems of law in this context, and in pursuit of the 'larger dream' of gender justice. ${ }^{164}$ For the international lawyer, modesty about what the law can accomplish is an important virtue. ${ }^{165}$

160 See further Hearn Jane and Harris Susan 'Debating the relationship between human rights and aid in Australia' (2002) 59 Development Bulletin Development Studies Network 77.

161 Rothstein Robert L cited by Lambourne Wendy 'Post-Conflict Peacebuilding: Meeting human needs for justice and reconciliation' (2004) 4 Peace, Conflict and Development 2.

162 Leebaw above note 16 at 364 .

163 My thanks to James Hathaway for this suggestion.

164 Bell and O'Rourke above note 50 at 44.

165 Drumbl above note 32 at 10. 
Copyright of Full Text rests with the original copyright owner and, except as permitted under the Copyright Act 1968, copying this copyright material is prohibited without the permission of the owner or its exclusive licensee or agent or by way of a license from Copyright Agency Limited. For information about such licences contact Copyright Agency Limited on (02) 93947600 (ph) or (02) 93947601 (fax) 